\title{
Az Egyek-pusztakócsi mocsarak (Hortobágyi Nemzeti Park) kétéltüfaunája
}

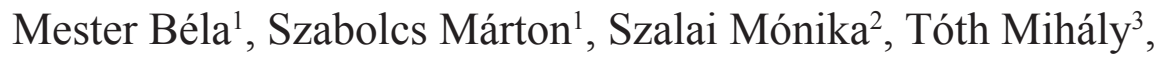 \\ Mérő Thomas Oliver ${ }^{1,4}$, Szepesváry Csaba ${ }^{1}$, Polyák László ${ }^{5}$, Puky \\ Miklós $^{6 \dagger}$ és Lengyel Szabolcs ${ }^{1}$
}

${ }^{1}$ MTA Ökológiai Kutatóközpont (ÖK), Duna-kutató Intézet (DKI), Tisza-kutató Osztály, 4026 Debrecen, Bem tér $18 / \mathrm{c}$

${ }^{2}$ Körös-Maros Nemzeti Park Igazgatóság, Természetmegőrzési és Pályázatkezelési Osztály, 5540 Szarvas, Anna-liget 1.

${ }^{3}$ Orségi Nemzeti Park Igazgatóság, 9941 Öriszentpéter, Siskaszer 26/a

${ }^{4}$ Természetvédelmi és Természettani Egyesület - NATURA, 25000 Zombor, Milana Rakića 20, Szerbia

${ }^{5}$ BioAqua Pro Kft., 4032 Debrecen, Soó Rezsö utca 21.

${ }^{6}$ MTA ÖK, DKI, Restaurációs- és Állatökológiai Osztály, 1113 Budapest, Karolina út 29.

e-mail: mester.bela@okologia.mta.hu

\begin{abstract}
Összefoglaló: A kétéltủek (Amphibia) globálisan az egyik legveszélyeztetettebb élőlénycsoport, ezért elterjedésük ismerete alapvetően fontos, különösen olyan védett területeken, ahonnan kevés a korábbi információ és aktív beavatkozások zajlanak. Jelen munkánkban összesítjük az Egyekpusztakócsi mocsarak területén több korábbi vizsgálatban végzett felméréseink faunisztikai eredményeit, melyeket ötféle mintavételi módszerrel gyüjtöttünk 15 darab 2,5×2,5 kilométeres UTM cellában. Összesen 11 kétéltüfaj (pettyes gőte, dunai tarajosgőte, vöröshasú unka, barna ásóbéka, barna varangy, zöld varangy, zöld levelibéka, mocsári béka, kis tavibéka, nagy tavibéka, kecskebéka) 14 362 egyedét figyeltük meg. A hat legjobban felmért UTM négyzet között nem volt jelentős eltérés a diverzitás tekintetében. Két 10x10 kilométeres UTM négyzet (DT86 és 96) esetében öt és hét faj jelenlétével bővültek ismereteink. Nagy állományokkal volt jelen két Natura 2000-es jelölőfaj, a vöröshasú unka és a dunai tarajosgőte. Eredményeink szerint a mocsárrendszer a tájrehabilitációs beavatkozásoknak köszönhetően értékes és diverz kétéltűfaunának szolgál otthonául, ezért megfelelő kezelése és védelme kiemelt fontossággal bír.
\end{abstract}

Kulcsszavak: Anura, Caudata, élőhelykezelés, herpetofauna, Hortobágy, monitorozás, Natura 2000, rekonstrukció 


\section{Bevezetés}

A kétéltüek populációinak fogyatkozása és eltűnése világméretü jelenség (Beebee \& Griffiths 2005, Frost 2017). A folyamat elsődleges kiváltó oka az emberi civilizáció egyre növekvő területigénye (Hamer \& McDonnell 2008), amely Európában a természetes élőhelyek összezsugorodásához, feldarabolódásához majd eltűnéséhez vezet (Sanderson et al. 2002). Az ember térnyerésével együtt az elmúlt húsz év során világszerte megjelent a kitridiomikózis, amely a kétéltủek rajzóspórás kitrid gomba (Batrachochytrium dendrobatidis) általi megbetegedése (Collins 2010, Olson et al. 2013, Alroy 2015). Kétfázisú életmódjuk miatt a kétéltüeknek a megfelelő minőségü édesvízi élőhelyek mellett szükségük van az azokat övező és összekötő szárazföldi élőhelyekre is, melyek vonulási útvonalat, táplálkozóhelyet, illetve nyári és téli búvóhelyet biztosítanak számukra (Semlitsch 2008). A Kárpátmedencében elhelyezkedő nagy kiterjedésü természetes, vagy természetközeli állapotú élőhelyek számos veszélyeztetett kétéltüfaj jelenleg még erős állományainak biztosítanak fennmaradást (Puky et al. 2005, Gubányi et al. 2010). A hazai élőhelyek feldarabolódása, leromlása és eltünése azonban a kétéltü-állományok fokozatos csökkenését eredményezi (Vörös et al. 2015). Annak ellenére, hogy a hazai kétéltűfajok több évtizede állnak természetvédelmi oltalom alatt, pontos hazai elterjedésükről mindmáig hiányosak ismereteink (Puky et al. 2005). Bár számos pontos előfordulási adatokat is közlő munka jelent meg korábban (mint például Méhely 1904, Fejérváry 1925, Dely 1959, Marián 1963, Dely 1966, Marián 1966, Dely 1981, Solti \& Varga 1981), hazánkban az első átfogó herpetofaunisztikai adatgyüjtés 1987-ben indult. Ezek a felmérések elsősorban a Duna-, a Tisza-, a Szamos- és az Ipoly-menti élőhelyekre fókuszáltak (Puky 2001b, Puky \& Fodor 2002, Puky 2007) és megalapozták az első magyar herpetológiai atlaszt (Puky et al. 2005). Ezt követően az ezredfordulóra elkészült egy közel 3000 megfigyelési adaton nyugvó UTM adatbázis (Bakó \& Korsós 1999), melyet további felmérések (Szép et al. 2011) és online adatgyüjtések követtek (MME „Herptérkép” adatbázis, Varangy Akciócsoport „Láss, alkoss, gyarapíts” fényképes adatgyüjtése). Az eddigi közlemények azonban arra is rámutatnak, hogy hazánkban több, kevésbé feltárt régió is található, mint amilyen a Hortobágyi Nemzeti Park területe (Bakó \& Korsós 1999, Puky et al. 2005, Gubányi et al. 2010).

A Hortobágy kistáj területéről elsőként Dely (1981) közölt részletes előfordulási adatokat, aki tíz faj jelenlétét említi: pettyes gőte (Lissotriton vulgaris L., 1758), dunai tarajosgőte (Triturus dobrogicus Kiritzescu, 1903), vöröshasú unka (Bombina bombina L., 1761), barna ásóbéka (Pelobates fuscus Laurenti, 1768), barna varangy (Bufo bufo L., 1758), zöld levelibéka (Hyla arborea L., 1758), mocsári béka (Rana arvalis Nilsson, 1842), 
erdei béka (Rana dalmatina Bonaparte, 1839), nagy tavibéka (Pelophylax ridibundus Pallas, 1771) és kecskebéka (Pelophylax kl. esculentus L., 1758). Endes (1988) további két fajt említ a Hortobágyról, a zöld varangyot (Bufotes viridis Laurenti, 1768) és a kis tavibékát (Pelophylax lessonae Camerano, 1882). A Dely (1981); és Endes (1988) által felsorolt fajok közül hat esetében (pettyes gőte, zöld varangy, mocsári béka, zöldbéka fajkomplexum) a fajnevek módosultak az újabb kutatások hatására (lásd; Frost 2017). Továbbá Dely (1981) és Endes (1988) a T. dobrogicus-t még tarajosgőteként (T. cristatus) említi, hiszen a dunai tarajosgőtét akkor még a tarajosgőte alfajaként kezelték (Frost 2017). Később Vörös \& Major (2007) molekuláris taxonómiai módszerekkel kimutatta, hogy a $T$. cristatus hazánkban csak T. cristatus/dobrogicus hibrid populációban van jelen az Aggteleki Nemzeti Park területén. Azonban a fent említett közlemények nem térnek ki a Hortobágy nyugati peremén található, a Nagykunság felé átmenetet mutató „Egyek-pusztakócsi mocsarak” tájegység kétéltűfaunájára.

Jelen cikk célja (i) ismertetni az Egyek-pusztakócsi mocsárrendszer kétéltűfajait, (ii) adatokat közölni azok előfordulásáról a vizsgált 2,5x2,5 és 10x10 kilométeres UTM négyzetekben, valamint (iii) röviden összehasonlítani az alkalmazott vizsgálati módszereket.

\section{Módszerek}

A 4073 hektár összterületü, asztatikus mocsarakból, az azokat övező rétekből, szikes és löszgyepekből álló Egyek-pusztakócsi mocsárrendszer a pleisztocén kor óta a Tisza természetes ártere (Aradi et al. 2003). A XIX. század közepére befejezett folyószabályozási munkálatokat követően a mocsarakat lecsapolták és az így nyert területeket mezőgazdasági müvelésbe vonták. A mocsarak, rétek és gyepek fokozatos eltünésének visszafordítása érdekében 1976-ban kezdődött egy nagy léptékủ tájrehabilitációs program, amelynek első ütemeként a mocsarak vízutánpótlását biztosították csatornák létrehozásával. Ezt követően 2005 és 2009 között egy LIFE-Nature pályázat keretében megvalósult a rehabilitáció második üteme, mely során 760 hektáron végeztek visszagyepesítést a mocsarakat övező szántókon (2005-2008), valamint természetvédelmi kezelésekkel (égetés: 2007, 2009, legeltetés: 2006-) állították vissza a mocsarak egykori változatosságát (Lengyel et al. 2012). A beavatkozások hatásának felmérése céljából 2004 óta végzünk a területen monitorozó és ökológiai vizsgálatokat (Nagy \& Lengyel 2008, Rácz et al. 2013, Mérő et al. 2015), melyek a rehabilitációs program második ütemének lezárását követően 2010-töl a kétéltüek csoportját is magukban foglalják (Mester et al. 2015a, Mester et al. 2015b). 
Vizsgálatainkat március elejétől október közepéig végeztük összesen 52 terepnap során, alkalmazkodva az időjáráshoz és a vegetációs periódushoz. A 2010 és 2016 között az Egyek-pusztakócsi mocsárrendszerben végzett felméréseink során ötféle vizsgálati módszerrel dolgoztunk: (i) vizuális megfigyelés (vonal menti számlálás, kézi hálós mintavétel minden élőhelytípusban és útfelmérés), (ii) nappali és esti hangmonitorozás vizes élőhelyek mentén, (iii) nappali, transzektek (100 m) mentén végzett akusztikus és vizuális megfigyelés mocsarakban, (iv) palackcsapdázás mocsarakban és csatornákban (Heyer et al. 1994, Anthony \& Puky 2001, Puky 2001a, Kiss et al. 2005) és (v) Barber-féle talajcsapdázás gyepen (rét, szikes, lösz). A talajcsapdákat a gyeprekonstrukció ízeltlábúakra gyakorolt hatásának vizsgálatára helyeztük ki, de ellenőrzésük (4-5 csapdaellenőrzés/év) során feljegyeztük az azokba beleesett kétéltüeket is (Mester et al. 2015a).

$\mathrm{Az}$ adatok térinformatikai megjelenítéséhez, kezeléséhez és értékeléséhez Garmin Base Camp 4.5 és Quantum GIS 2.16.2 szoftvereket használtuk. A korábbi országos adatbázisokkal való kompatibilitás érdekében eredményeinket megadjuk 2,5x2,5 és 10x10 kilométeres UTM hálóban is, melyeket az MME Monitoring Központ bocsátott a rendelkezésünkre (Szép \& Nagy 2001). Mivel a 15 darab 2,5×2,5 kilométeres UTM négyzetből hat UTM-cella esetében 60\%-nál nagyobb volt a mintavételi terület UTM négyzethez viszonyított területi aránya (1. táblázat, 1. ábra), így ezeknek a celláknak a diverzitását Rényi-féle diverzitásrendezéssel hasonlítottuk össze PAST 3.15-ben (Hammer et al. 2001, Magura et al. 2010).

\section{Eredmények}

Összesen 11 kétéltűfaj 14362 egyedének előfordulását regisztráltuk az Egyekpusztakócsi mocsárrendszerben (1. táblázat). A kétéltúek 71\%-a fordult elő a hat legjobban lefedett 2,5x2,5 kilométeres UTM négyzetben (1. táblázat), habár már a 60\%-nál kisebb lefedettségü UTM négyzetek esetében is kimutattuk mind a 11 fajt (1. táblázat). A hat legjobb lefedettségü négyzet diverzitásprofilja metszette egymást (2. ábra), így ezek a diverzitás tekintetében nem különböztek. A négy érintett 10x10 kilométeres UTM négyzet közül kettőben (DT96 és 97) mind a 11 fajt kimutattuk, kettőben pedig hat (DT86) és öt (DT87) fajt találtunk (2. táblázat).

\section{Pettyes göte}

Összesen 302 egyedét figyeltük meg, ez az összes megfigyelt egyed 2\%-át jelenti. Kilenc 2,5x2,5 kilométeres UTM négyzetben regisztráltuk a jelenlétét (1. táblázat). A pettyes gőték túlnyomó többségét talajcsapdázással észleltük, de vizuális megfigyelés és palackcsapdázás során is kerültek elő példányok (3. ábra). Palack- 


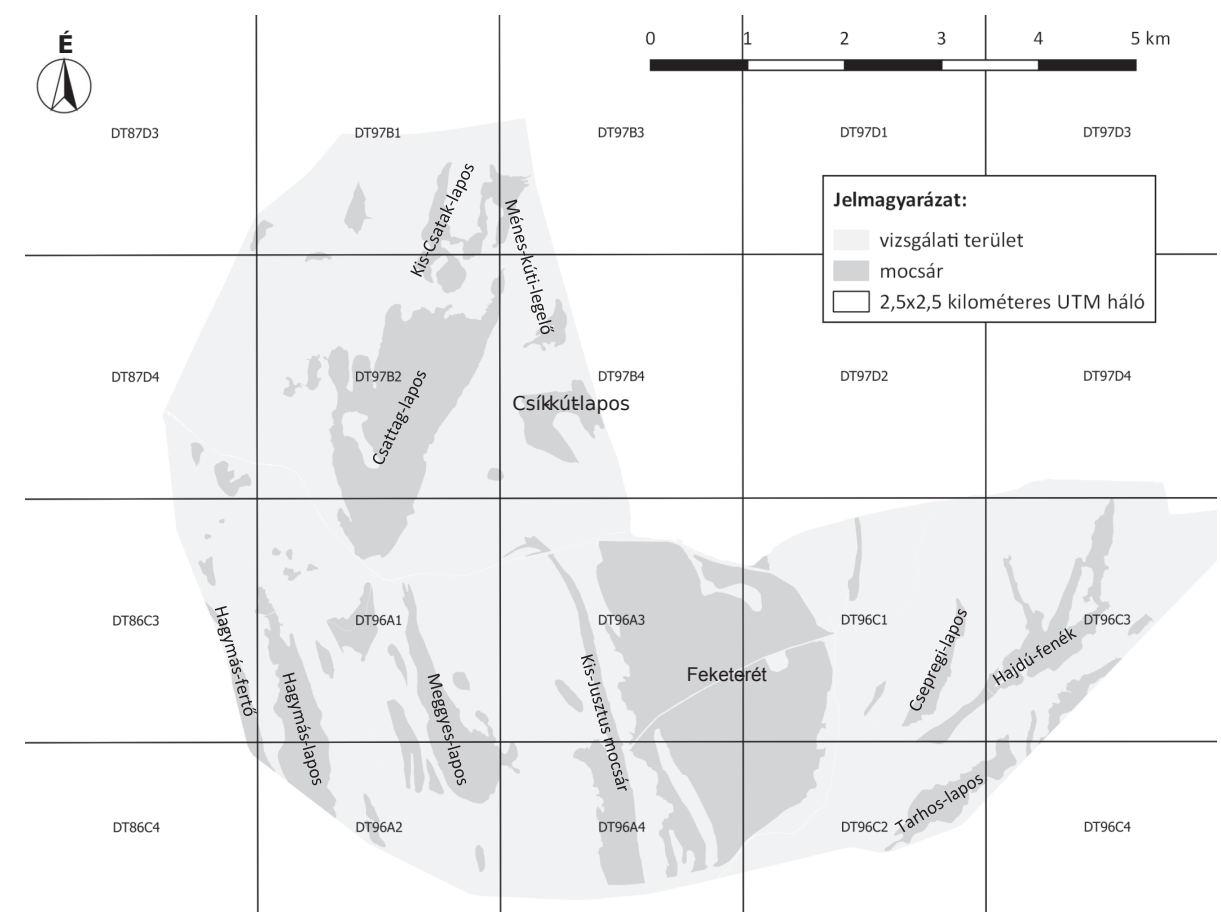

1. ábra. A vizsgálati terület (Egyek-pusztakócsi mocsárrendszer) kiterjedése, a nagyobb mocsarak elhelyezkedése és a terület 2,5×2,5 kilométeres UTM négyzetekkel való lefedettsége.

csapdázással lárvákat, vizuális megfigyelés során adult gőtéket, talajcsapdázással pedig szinte kizárólag friss metamorf példányokat találtunk. A pettyes gőte gyakorinak bizonyult a nagy kiterjedésủ mocsarak közelében, mint a Fekete-rét, a Csattag-lapos, a Hagymás-lapos és a Hajdú-fenék (1. ábra). Nászruhás példányait legkorábban 2013. április elején figyeltük meg a Fekete-rét frissen rekonstruált csónakútja mentén. Lárváit 2012. július végén fogtuk palackcsapdázással a kiszáradó, sekély, átlagosan 14 cm vízmélységü Hagymás-laposban, egy nádsziget szegélyében. Legkésőbb október közepén figyeltük meg (4. ábra). Gyakori kétéltüfajnak tekinthető a mocsárrendszerben, de előfordulása foltszerü, a nagyobb laposok és erdőfoltok mentén gyakoribb.

\section{Dunai tarajosgöte}

Összesen 1652 egyedét figyeltük meg, ez az összes megfigyelés $12 \%$-át jelenti. Tizenkét UTM cellában észleltük a jelenlétét (1. táblázat). Hasonlóan a pettyes gőtéhez, a dunai gőtét is föként talajcsapdákból mutattuk ki (3. ábra), ahol a fogott egyedek több mint 90\%-a friss metamorf példány volt. Palackcsapdázással 2012. 


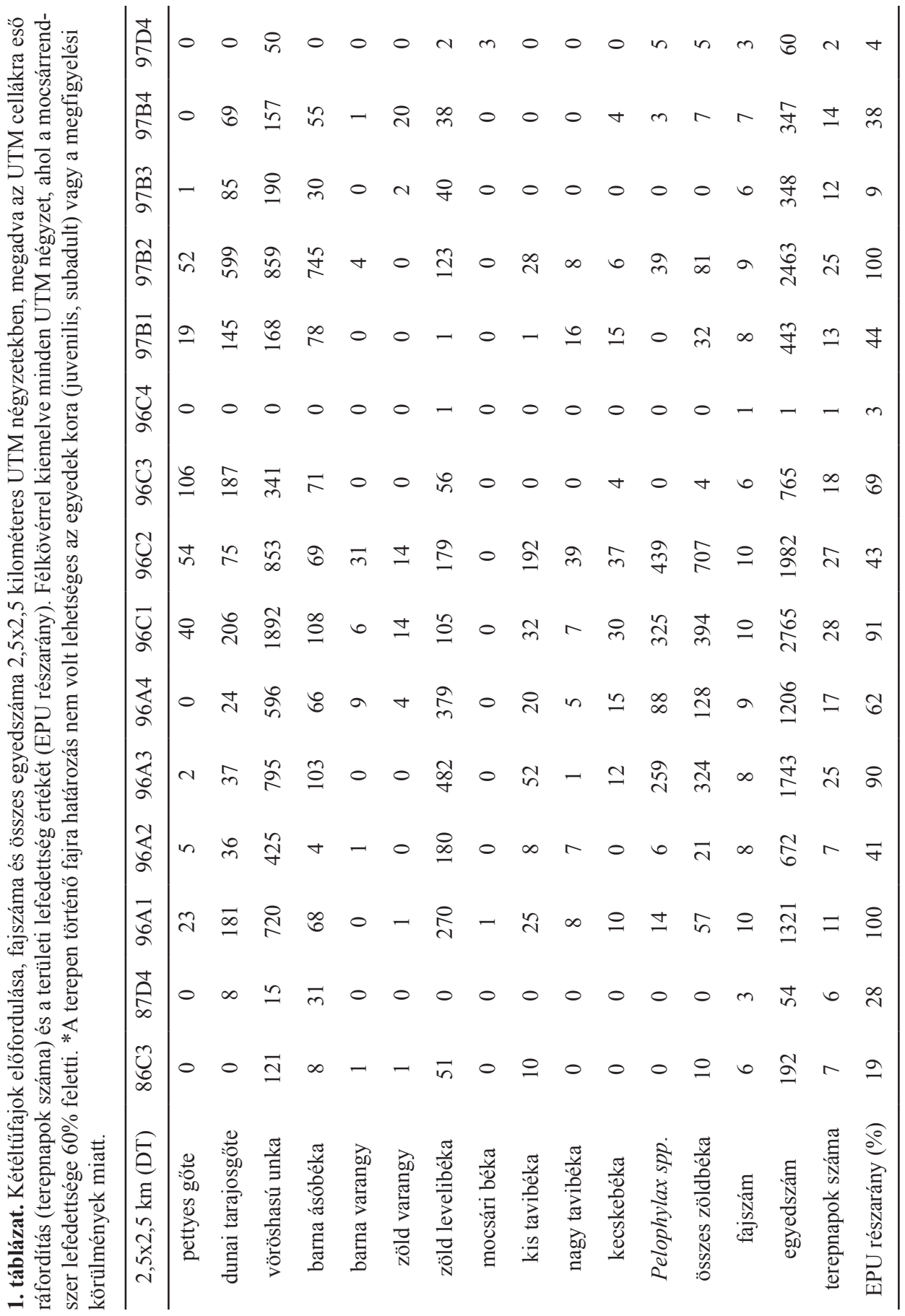


2. táblázat. Kétéltűfajok előfordulása, fajszáma (korábban leírt fajszám) 10 kilométeres UTM négyzetekben, megadva az UTM cellákra eső ráfordítás (felmérési alkalom) és területi lefedettség (százalékos) értékét, a fajok Natura 2000 besorolását, az IUCN szerinti veszélyeztetettségét és populációs trendjeiket. (V=előfordulása valószínűsíthető, $1=$ saját adat, $1=$ saját adat és új előfordulás, $*$ =herpetológiai atlasz (Puky et al. 2005) alapadatai, **=egyéb irodalom)

\begin{tabular}{|c|c|c|c|c|c|c|}
\hline $10 \times 10 \mathrm{~km}(\mathrm{DT})$ & 86 & 87 & 96 & 97 & $\begin{array}{l}\text { Élőhelyvédel- } \\
\text { mi Irányelv } \\
\text { Függeléke }\end{array}$ & $\begin{array}{l}\text { globális } \\
\text { populációs } \\
\text { trend }\end{array}$ \\
\hline pettyes göte & $\mathrm{V}$ & $*$ & 1 & 1 & - & stabil \\
\hline dunai tarajosgőte & $\mathrm{V}$ & $1^{*}$ & $1 * / * *$ & $1 * / * *$ & II & csökkenő \\
\hline vöröshasú unka & 1 & $1 *$ & $1^{*}$ & $1 * / * *$ & II & csökkenő \\
\hline barna ásóbéka & 1 & $1 *$ & 1 & $1 *$ & IV & csökkenő \\
\hline barna varangy & 1 & $*$ & 1 & $1 *$ & - & stabil \\
\hline zöld varangy & 1 & $*$ & $1^{*}$ & $1 *$ & IV & csökkenő \\
\hline zöld levelibéka & $1^{*}$ & $\mathrm{~V}$ & 1 & $1^{*}$ & IV & csökkenő \\
\hline mocsári béka & - & $1^{*}$ & 1 & $1^{*}$ & IV & stabil \\
\hline erdei béka & - & - & - & - & IV & csökkenö \\
\hline kis tavibéka & 1 & $1 *$ & 1 & $1^{*}$ & IV & csökkenő \\
\hline nagy tavibéka & V & $*$ & 1 & $1^{*}$ & $\mathrm{~V}$ & növekvő \\
\hline kecskebéka & $*$ & $*$ & $1^{*}$ & $1^{*}$ & V & csökkenő \\
\hline fajszám (korábbi) & $6(1)$ & 10 & $11(4)$ & 11 & & \\
\hline terepnapok száma & 6 & 6 & 46 & 27 & & \\
\hline UTM részarány (\%) & 1,8 & 11,9 & 31,1 & 12,1 & & \\
\hline
\end{tabular}

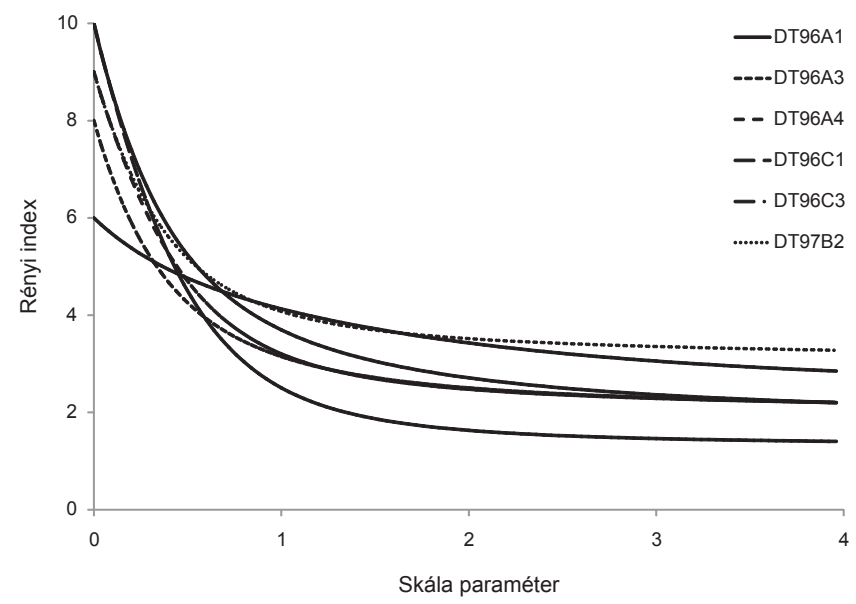

2. ábra. A hat legjobb lefedettségű 2,5x2,5 kilométeres UTM cella kétéltủegyütteseinek diverzitási rendezése a Rényi-féle általánosított entrópia szerint. 
július végén a Fekete-rét melletti árasztó csatornában fogtunk két adult hímet és két nőstényt. Vizuális megfigyeléssel 2010 októberében a Csattag-lapos melletti réten és szikes gyepen, illetve 2013 áprilisában a fekete-réti rekonstruált csónakút

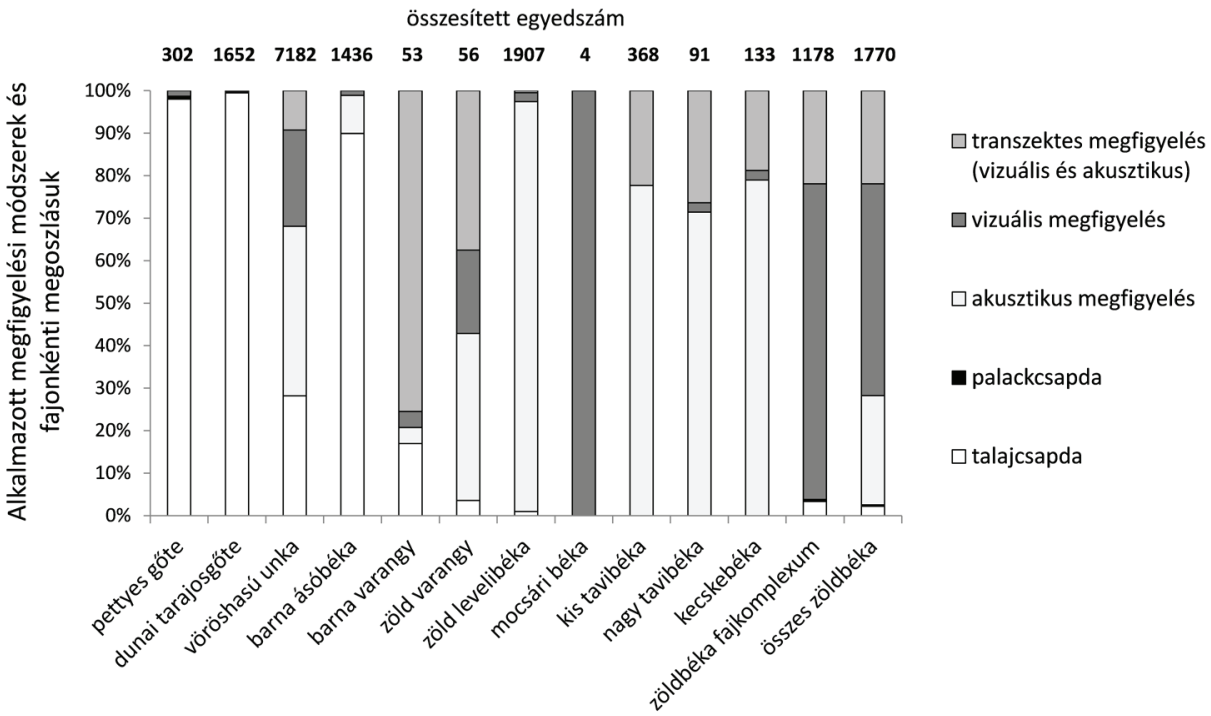

3. ábra. Alkalmazott megfigyelési módszerek és azok aránya az észlelt fajokon belül kiegészítve azok összesített egyedszámával.

mentén észleltünk adult dunai tarajosgötéket (1. ábra). Legkorábban március közepén útfelmérés során észleltük, legkésőbbi adata október közepéről származik (4. ábra). A dunai tarajosgőte gyakorinak, a nagyobb mocsarak (Fekete-rét, Csattag-lapos) esetében időnként tömegesnek tekinthető (1. ábra). Nedvesebb években, ősszel a pettyes gőténél gyakrabban lehet vele találkozni a mocsarak közötti, magasabb vegetációjú gyepeken is.

\section{Vöröshasú unka}

Összesen 7182 példányát figyeltük meg, ez az összes észlelt egyedszám fele. Egy kivételével az összes UTM négyzetben kimutattuk a jelenlétét (1. táblázat). A megfigyelt egyedek 40\%-át esti és nappali hangmonitorozás során észleltük, $32 \%$-ukat vizuális és kombinált módszerrel figyeltük meg, míg további 28\%ukat talajcsapdában találtuk (3. ábra), melyek túlnyomó többsége adult példány volt. Egy esetben palackcsapdázással is fogtunk egy adult, zöld színváltozatú példányt a Fekete-rét melletti árasztó csatornában (1. ábra, 3. ábra). 1406 egyed vizsgálata alapján a zöldhátú színváltozat gyakorisága átlagosan $8,5 \%$ (legkisebb mintaszám $n \geq 50$ esetén), összesítve pedig 9,7\%. Legkorábban március elején, 


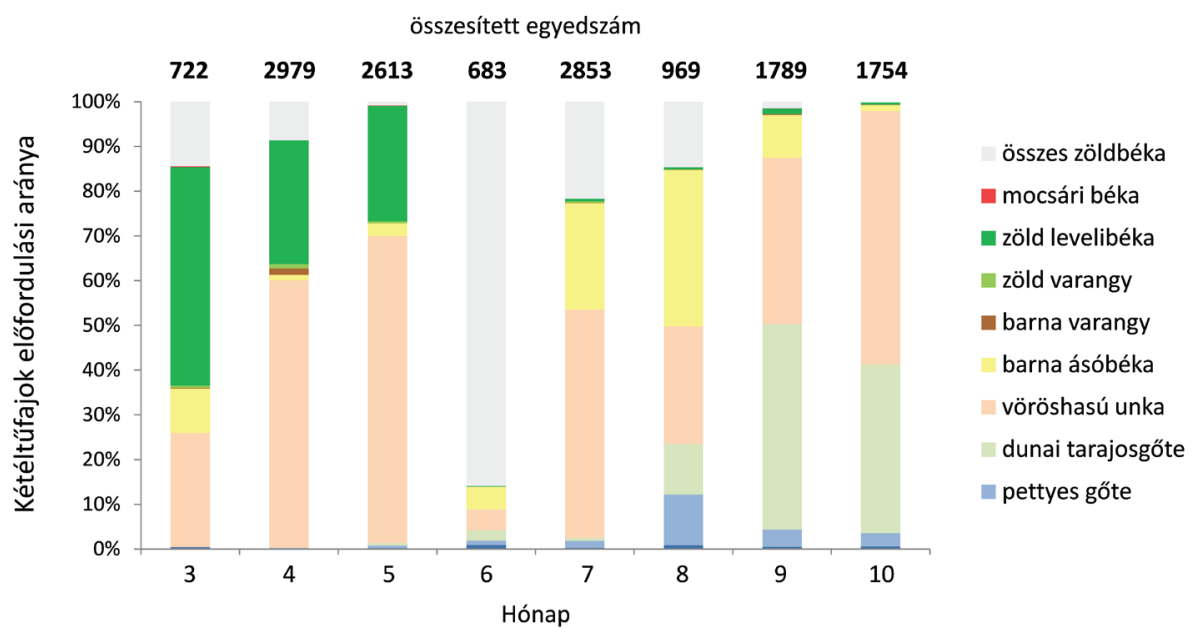

4. ábra. Kétéltűfajok előfordulási aránya havi bontásban kiegészítve az összesített egyedszámmal.

legkésőbb október közepén észleltük (4. ábra). A vöröshasú unka a mocsárrendszer leggyakoribb kétéltüfaja, minden vizes élőhelytípusban megtalálható, a nagyobb mocsarakban tömeges. Egyedsürüsége az arra alkalmas helyeken elérheti a 20000 példányt is hektáronként (Mester 2011). A mocsarakat övező rétzónában és a vizenyős szikeseken is gyakori. Nedvesebb években a mocsarakat összekötő magasabb löszhátakon is tömegesen mozoghatnak.

\section{Barna ásóbéka}

Összesen 1436 egyedét észleltük vizsgálataink során, ami 10\%-át adja a kétéltủek összes egyedszámának. Tizenhárom UTM cellában észleltük (1. táblázat). Hasonlóan a gőtékhez, az ásóbékák mintegy 90\%-át is talajcsapdával detektáltuk. Kilenc százalékukat hangmonitorozással észleltük tavasszal, a nagy mocsarak rétzónájában. Tizenhat példányt vizuális keresés során figyeltünk meg. 2012. július végén palackcsapdával egy ásóbéka ebihalat fogtunk a Hagymás-lapos déli szegélyében (1. ábra, 3. ábra). Ebihalait július közepétől augusztus elejéig a nagyobb mocsarak sekély vizü rétzónájában néha tömegesen lehet megfigyelni, például a Csattag-lapos nyugati és déli rétzónájában (1. ábra). A vizuális és talajcsapdás módon megfigyelt egyedek 15\%-a volt friss metamorf példány. Legkorábbi adata március elejéről származik, legkésőbb október közepén láttuk a fajt (4. ábra). Gyakori kétéltűnek tekinthető, a mocsarakat elválasztó löszhátakon néha tömegesen fordul elö. 


\section{Barna varangy}

Összesen 53 példányát észleltük a vizsgálati területen, ami az összes egyedszám kevesebb, mint 1\%-át adja. Hét cellában detektáltuk a jelenlétét (1. táblázat). Az egyedek 75\%-át kombinált vonal menti számlálás során észleltük (3. ábra), hang alapján a Fekete-rét mocsár déli részén (1. ábra, 3. ábra). További két példányt detektáltunk hangmonitorozással (3. ábra), az egyiket a fekete-réti rekonstruált csónakázó tó szélén, a másikat a Hagymás-laposban (1. ábra). Vizuális kereséssel két példányt, talajcsapdázással kilenc egyedet észleltünk (3. ábra). A megfigyelt egyedek 94\%-a adult példány volt. A talajcsapdákban egy adult példány kivételével juvenilis barna varangyokat találtunk. A legkorábbi adata március végéröl, a legkésőbbi októberből származik (4. ábra). Ritkább fajnak tekinthető, elszórtan lehet vele találkozni a mocsárrendszerben.

\section{Zöld varangy}

Összesen 56 példányát figyeltük meg, ami $1 \%$ alatti arányt jelent az összes egyedszámhoz képest. A fajt hét UTM négyzetből mutattuk ki (1. táblázat). Az egyedek 77\%-át akusztikus módszerrel észleltük hangmonitorozás és kombinált transzektes megfigyelések során. Vizuális módon összesen 11 adult egyedet figyeltünk meg (3. ábra), talajcsapdában pedig egy subadult és egy adult egyedet találtunk. Legkorábban március 16-án figyeltünk meg zöld varangyot, a legkésőbbi adata július végéről származik (4. ábra). A tanyák és települések közelében gyakrabban fordul elő. Bizonyos években a következő sekély vizü élőhelyeken észleltük őket: KisCsatak-lapos, Ménes-kúti-legelö, Csík-kút-lapos, Csattag-lapos déli része, Hagymás-fertő és Hajdú-fenék (1. ábra). A barna varangynál valamivel gyakoribb, de szórványosan előforduló kétélünek tekinthető a területen.

\section{Zöld levelibéka}

Összesen 1907 példányát figyeltük meg, ez 13\%-os gyakoriságot jelent az összes egyedszámhoz képest. Tizennégy UTM cellából mutattuk ki (1. táblázat). A megfigyelt egyedek 97\%-át hangmonitorozással észleltük a nagyobb kiterjedésü, náddal és gyékénnyel sürübben borított mocsarakban és a réteken. Összesen 49 példányt találtunk vizuális módszerekkel (3. ábra), többségüket a Fekete-rét területén (1. ábra), de szikes és löszgyepen is megfigyeltük. A talajcsapdákban összesen 18 levelibékát találtunk (3. ábra), ezekből rekonstruált gyepen volt hét példány 2010ben, 2013-ban pedig egy mocsár melletti csapdában 11 egyedet fogtunk. Mindöszsze egy juvenilis példányát észleltük, amelyet szikes gyepen fogtuk 2016. június elején. Március elejétől október közepéig találtunk zöld levelibékát a területen (4. ábra). Gyakori fajnak tekinthető a mocsárrendszer teljes területén, amely a sza- 
porodási időszakot követően a ritkásabb nádasok mellett megtalálható a bokros, bozótos és fás ligetek mentén is.

\section{Mocsári béka}

Mindössze négy egyedét sikerült megfigyelni a vizsgálati évek során, így ez volt a legritkább kétéltüfaj. Összesen két UTM cellából ismert az előfordulása (1. táblázat). Kizárólag vizuális módon észleltük (3. ábra); 2011. szeptember végén szikes gyeprekonstrukción találtunk egy adult példányt, 2012. május elején a Megygyes-erdőben találtunk két adult mocsári békát, majd 2014 márciusában szintén a Meggyes-erdőben láttunk egy subadult példányt (1. ábra).

\section{Zöldbéka fajkomplexum}

Összesen 1770 megfigyelt egyeddel a zöldbékafajok az összes egyedszám 12\%át adják. Ebből 1178 egyed fajra történő pontos határozása nem volt lehetséges az egyedek kora (subadult) vagy az észlelés minősége miatt. Akusztikus megfigyeléssel a zöldbékák fennmaradó 33\%-át tudtuk fajra határozni. A nappali és esti hangmonitorozás során összesen 368 kis tavibékát, 133 kecskebékát és 91 nagy tavibékát észleltünk (lásd 3. ábra). Az előbbi két faj kilenc UTM cellában, míg utóbbi nyolcban fordult elő (1. táblázat). A megfigyelt zöldbékák 52\%-a volt subadult. 2012. július végén palackcsapdával fogtunk hat zöldbéka ebihalat, a talajcsapdákban pedig kizárólag friss metamorf példányokat. Március elejétől október közepéig találtunk zöldbéka egyedeket a területen (4. ábra). A zöldbékafajok az egész mocsárrendszer területén gyakoriak, elsősorban a mocsarakban és az azok közelében található kisebb állóvizekben.

\section{Értékelés}

Jelen cikkünk elsőként közöl átfogó és részletes leírást az Egyek-pusztakócsi mocsárrendszer kétéltüfaunájáról. Eredményeink szerint az erdei béka (Rana dalmatina Bonaparte, 1840) kivételével a Magyarországon előforduló összes síkvidéki kétéltüfaj megtalálható a mocsárrendszerben (1. táblázat). Az erdei béka legközelebb a Tisza menti ártéri és hullámtéri erdőkben fordul elö (Marián 1963, Puky et al. 2005). Munkánk számos új rekorddal bővíti az országos UTM-alapú adatbázist minden faj tekintetében, kivéve a dunai tarajosgőtét. A dunai tarajosgőte a DT86-os cella kivételével az összes 10x10 km-es UTM négyzetben előfordult. A DT86 és DT96-os cellákat újabb elöfordulási adatokkal bővítettük az összes faj esetében (2. táblázat). A DT97-es négyzetben, amely magában foglalja a Csattaglapost és az attól északra található kisebb mocsárfoltokat, korábban már ismert 
volt mind a 11 kétéltüfaj jelenléte (Puky et al. 2005, Gubányi et al. 2010). Ezzel szemben a DT96-os cellában, amely lefed hat nagy kiterjedésủ mocsarat, köztük a mocsárrendszer legnagyobb mocsarával, a Fekete-réttel, csupán négy taxon jelenléte volt ismert korábban (dunai tarajosgőte, vöröshasú unka, zöld varangy, Pelophylax spp.) (Puky et al. 2005, Gubányi et al. 2010). A DT86-os UTM négyzet lefedi a Hagymás-fertőt. A DT86-os cellából az eddig leírt zöld levelibéka és kecskebéka mellett öt további faj előfordulását bizonyítottuk. A Hagymás-fertőben valószínüsíthetö a pettyes és a dunai tarajosgőte előfordulása is, mivel a közeli Hagymás-laposban megtalálható mindkét faj. A nagy tavibéka szintén előfordulhat a mocsár mélyebb, tartósabb vízborítottságú részein. A DT87-es UTM négyzetböl hiányzik ugyan a zöld levelibéka, de előfordulása valószínúsíthető a nagyobb mocsarak közelsége és a faj nagy mozgáskörzete miatt (Smith \& Green 2005). A legtöbbet látogatott hat UTM négyzet, amelyekben a mocsárrendszer területi lefedettsége is nagyobb volt, a diverzitás tekintetében nem tért el egymástól (2. ábra), mely utalt a fajok közel egyenletes eloszlására a mocsárrendszeren belül. Ez nem meglepő, mivel a négyzetek lefednek minden jelentősebb mocsarat, melyek megfelelő szaporodó-, táplálkozó- és telelőhelyet jelentenek (1. táblázat, 1. ábra).

A gőtefajok és a szárazföldi életmódú barna ásóbékák kimutatásában hatékony volt a gyepeken végzett talajcsapdázás, hiszen a terresztris életciklusban lévő kétéltüek optimális klimatikus viszonyok esetén (esős, nyirkos esték) intenzíven vándorolnak a mocsarakat elválasztó löszhátakon (Semlitsch 2008). Ilyenkor a Barber-csapdák a kétéltủek fogását célzó talajcsapdákhoz hasonlóan egyfajta nedves búvóhelyként bevonzzák a közelben mozgó egyedeket (Kogut \& Padley 1997). A gőtefajok és ebihalak jelenléte kimutatható még palackcsapdázással is a szaporodási időszakon túl (Korsós 1997), ha egy adott mintavételi ponton megfelelő mennyiségű csapdát helyezünk ki. A hangmonitorozás költséghatékony módszer, amely alkalmas a békafajok jelenlétének kimutatására, állományuk becslésére és monitorozására (Anthony \& Puky 2001, Tóth \& Puky 2009). A hangmonitorozás további előnye, hogy a morfológiai alapon bizonytalanul határozható három zöldbékafaj egyedeinek többsége jól elkülöníthető hívóhangjuk alapján (Arnold \& Ovenden 2005, Glandt 2015). A három zöldbékafaj lokális populációs rendszereinek pontos viszonyait célzott, nagy mintaszámú és lefedettségü genetikai vizsgálatokkal lehet csak megállapítani a fajkomplexumra jellemző összetett hibridizációs mechanizmusok miatt (Vitt \& Caldwell 2014). Herczeg et al. (2016) vizsgálatai alapján az Egyek-pusztakócsi mocsárrendszerre a kis tavibéka és kecskebéka által alkotott „LE” típusú populációs rendszer lehet jellemző, amely egybeesik saját megfigyeléseinkkel. A vizuális módszerekkel (nappali és esti vizuális keresés és kézi hálózás) minden faj esetében találtunk egyedeket. A kétéltüfauna 
feltárása szempontjából az alkalmazott módszerek kombinációja és időzítése tavaszi (március közepe - május eleje), nyári (június vége - július vége) és őszi (szeptember közepe - október vége) periódusok, lásd a 4. ábrán - pontosabb eredményekhez vezet a terepi kiszállások gyakoriságának növelése mellett (Sewell 2006, Garden et al. 2007, Mattfeldt \& Grant 2007).

Az Egyek-pusztakócsi mocsarak és az azokat övező gyepek gazdag kétéltüfaunának biztosítanak élőhelyet. A gyakori, esetenként tömeges fajok közül kiemelendő a Natura 2000 jelölőfajként is számon tartott dunai tarajosgőte és vöröshasú unka, melyeknek erős állományai vannak jelen. A mocsárrendszer kétéltüi, különösen a barna ásóbéka és az előző két faj, érzékenyen reagálnak az édesvizek szennyezettségére (Wagner et al. 2014), ezért nagy jelentőséggel bír a mocsárrendszer területén érvényes mezőgazdasági vegyszerhasználattal kapcsolatos korlátozás. A túlzott vegyszerhasználat hatására kialakuló morfológiai elváltozások hiánya arra utalhat, hogy a mocsárrendszer egészére alacsony környezeti terhelés és szennyezés lehet jellemző (Mester et al. 2015a). A mocsarak természetes állapotának fenntartásában alapvető fontossággal bír a megfelelő élőhely-kezelési mód (kis intenzitású legeltetés és égetés pár évente), amely elősegítheti a kétéltüek sikeres reprodukcióját (Mester et al. 2015b). A csapadékhiányos, száraz évek során a mocsarak megfelelö vízutánpótlása szintén fontos a vízhez szorosabban kötődő fajok (pettyes és dunai tarajosgőte, vöröshasú unka, zöldbékák) védelme szempontjából (Semlitsch 2000, Tóth \& Puky 2009, Hamer et al. 2016). A rekonstruált és természetes gyepek mint zöld folyosók továbbá fontos szerepet játszanak a kétéltüek mocsarak közötti diszperziójában és a szaporódóhelyekre történő vonulásában (Semlitsch 2008), ezért a gyepek védelme és megfelelő kezelése ugyancsak fontos feladat (Smith \& Sutherland 2014).

\section{Etikai nyilatkozat}

Vizsgálatainkat a Hortobágyi Nemzeti Park Igazgatóság (HNPI) részvételével kivitelezett LIFE-Nature pályázat (LIFE04NAT/HU/000119,http://ife2004.hnp. hu) After-LIFE monitoring projektjének (2009-2014) keretén belül végeztük. A terepi mintavételi módszereket, közöttük a Barber-csapdák (talajcsapdák) ízeltlábúak begyüjtésére történő alkalmazását a Tiszántúli Környezetvédelmi, Természetvédelmi és Vízügyi Felügyelőség (TT KTVF) engedélyezte (engedély száma: 7901/3/2009). A talajcsapdák sajnálatos módon kétéltủeket is begyüjtöttek. Ugyanakkor a kétéltüek 80\%-át csapadékos évek során $(2010,2013)$ fogtuk, amikor a többi vizsgálati évhez viszonyítva kimagasló volt a kétéltűek száma és vonulási aktivitása. A csapdákban talált kétéltủek közül csak néhány egyedet találtunk 
élve, ezeket azonnal megtisztítottuk és szabadon engedtük egy távolabbi biztonságos helyen. Az elpusztult példányokat a csapdák újratöltése során eltávolítottuk a helyszínről. A nagy időközökkel történő ellenőrzések miatt azonban biztosan nem tudhatjuk, hogy az esetlegesen bejutó kétéltüek közül valójában hány egyed volt képes élve elhagyni a csapdákat (pl. esővízzel megtelt és kihígult csapdák esetében). A kétéltűek szaporodási időszakot követő vonulási orientációja miatt (lásd például; Joly \& Miaud 1993, Malmgren 2002, Semlitsch 2008) azonban valószínüsíthető, hogy a talajcsapdák a teljes állomány töredékét fogták meg csupán. Így miután a kétéltủek nem kívánatos begyüjtése és pusztulása csak az ízeltlábúak fogási valószínüségének jelentős csökkentésével mérsékelhető (pl. a fedél szoros illesztése, stb.), illetve a csapdázás szüneteltetése jelentős adathiányt eredményez, ezért a HNPI a vizsgálatok folytatása mellett döntött. Ugyanakkor a talajcsapdázás hozzájárult a terület kevésbé ismert kétéltüfaunájának feltárásához és a természetvédelmi beavatkozások hatásának vizsgálatát is lehetővé tette számos állatcsoport esetében. Az így kapott eredmények rendkívül értékesek mind a hazai, mind pedig a nemzetközi természetvédelem számára.

\section{Irodalomjegyzék}

Alroy, J. (2015): Current extinction rates of reptiles and amphibians. - Proc. Nat. Acad. Sci. USA 112: 13003-13008. doi: http://dx.doi.org/10.1073/pnas.1508681112

Anthony, B. \& Puky, M. (eds) (2001): Kétéltüek hang alapján történö monitorozása. - CentralEuropean University, Varangy Akciócsoport Egyesület, Budapest, 18 p.

Aradi, C., Göri, S. \& Lengyel, S. (2003): Az Egyek-Pusztakócsi mocsárrendszer. - In: Teplán, I. (szerk.): A Tisza és vízrendszere. MTA Társadalomkutató Központ, Budapest, pp. 277-298.

Arnold, E. N. \& Ovenden, D. (szerk.) (2005): A Field Guide to the Reptiles and Amphibians of Britain and Europe. - Collins, London, 288 p.

Bakó, B. \& Korsós, Z. (1999): A magyarországi herpetofauna U.T.M.-térképezésének felhasználási lehetöségei. - Állattani Közlem. 84: 43-52.

Beebee, T. J. C. \& Griffiths, R. A. (2005): The amphibian decline crisis: A watershed for conservation biology? - Biol. Conserv. 125: 271-285. doi: http://dx.doi.org/10.1016/j.biocon.2005.04.009

Collins, J. P. (2010): Amphibian decline and extinction: What we know and what we need to learn. - Dis. Aquat. Org. 92: 93-99. doi: http://dx.doi.org/10.3354/dao02307

Dely, O. G. (1959): Examen du Triton alpestre (Triturus alpestris Laurenti), spécialement en vue des populations de la Hongrie et des Carpathes. - Acta Zool. Acad. Sci. Hung. 5: 255-315.

Dely, O. G. (1966): Angaben über die Verbreitung des Feuersalamanders (Salamandra salamandra L.) im Karpatenbecken. - Vertebrata Hung. 8: 69-88.

Dely, O. G. (1981): Amphibians and reptiles of the Hortobágy. - In: Mahunka, S. (szerk.): The fauna of the Hortobágy National Park. Magyar Természettudományi Múzeum, Budapest, pp. 387-390.

Endes, M. (1988): A hortobágyi hal- kétéltü- és hüllőfauna ökológiai vizsgálata. - Calandrella 2: $41-56$. 
Fejérváry, G. G. (1925): Kétéltüek - Amphibia. - In: Szilády, Z. (szerk.): Nagy-Alföldünk állatvilága. Debreceni Tisza István tud. társ. honism. bizotts. közlem., Debrecen, pp. 138-144.

Frost, D. R. (2017): Amphibian Species of the World: an Online Reference Version 6.0 (2017.03.15). Electronic Database accessible at http://research.amnh.org/herpetology/amphibia/index.html. American Museum of Natural History, New York, USA.

Garden, J. G., McAlpine, C. A., Possingham, H. P. \& Jones, D. N. (2007): Using multiple survey methods to detect terrestrial reptiles and mammals: what are the most successful and cost-efficient combinations? - Wildlife Res. 34: 218-227. doi: http://dx.doi.org/10.1071/WR06111

Glandt, D. (szerk.) (2015): Die Amphibien und Reptilien Europas: Alle Arten im Porträt. - Quelle \& Meyer, Wiebelshelm, $550 \mathrm{p}$.

Gubányi, A., Vörös, J., Kiss, I., Dankovics, R., Babocsay, G., Kovács, T., Molnár, P. \& Somlai, T. (2010): Az alpesi tarajosgőte (Triturus carnifex), a dunai tarajosgőte (T. dobrogicus) és a vöröshasú unka (Bombina bombina) magyarországi elterjedésének elemzése. - Állattani Közlem. 95: 253-279.

Hamer, A. J., Heard, G. W., Urlus, J., Ricciardello, J., Schmidt, B. R., Quin, D. \& Steele, W. K. (2016): Manipulating wetland hydroperiod to improve occupancy rates by an endangered amphibian: modelling management scenarios. - J. Appl. Ecol. 53: 1842-1851. doi: http://dx.doi. org $/ 10.1111 / 1365-2664.12729$

Hamer, A. J. \& McDonnell, M. J. (2008): Amphibian ecology and conservation in the urbanising world: A review. - Biol. Conserv. 141: 2432-2449. doi: http://dx.doi.org/10.1016/j.biocon.2008.07.020

Hammer, O., Harper, D. A. T. \& Ryan, P. D. (2001): PAST: Paleontological statistics software package for education and data analysis. - Palaeontol. Electron. 4: 9.

Herczeg, D., Vörös, J., Christiansen, D. G., Benovics, M. \& Mikulícek, P. (2016): Taxonomic composition and ploidy level among European water frogs (Anura: Ranidae: Pelophylax) in eastern Hungary. - J Zool. Syst. Evol. Res. 55: 129-137. doi: http://dx.doi.org/10.1111/jzs.12158

Heyer, W. R., Donnelly, M. A., McDiarmid, R. W., Hayek, L. C. \& Foster, M. S. (szerk.) (1994): Measuring and Monitoring Biological Diversity: Standard Methods for Amphibians. - Smithsonian Institution Press, Washington D.C., 384 p.

Joly, P. \& Miaud, C. (1993): How does a newt find its pond? The role of chemical cues in migrating newts (Triturus alpestris). - Ethol. Ecol.\& Evol. 5: 447-455.

Kiss, I., Bakó, B., Dankovics, R., Kovács, T. \& Szénási, V. (2005): Kétéltűek és hüllők monitorozása a NBmR keretein belül 2004-2005. Kutatási jelentés, KvVM Természetvédelmi Hivatal, Budapest, $97 \mathrm{pp}$.

Kogut, N. \& Padley, W. D. (1997): A method for reducing mortalities in pitfall traps. - Transactions of the Western Section of the Wildlife Society 33: 75-78.

Korsós, Z. (1997): Nemzeti Biodiverzitás-monitorozó Rendszer VIII. Kétéltüek és hüllök. - Magyar Természettudományi Múzeum, Budapest, 48 p.

Lengyel, S., Varga, K., Kosztyi, B., Lontay, L., Déri, E., Török, P. \& Tóthmérész, B. (2012): Grassland restoration to conserve landscape-level biodiversity: a synthesis of early results from a large-scale project. - Appl. Veg. Sci. 15: 264-276. doi: http://dx.doi.org/10.1111/j.1654109X.2011.01179.X

Magura, T., Lövei, G. L. \& Tóthmérész, B. (2010): Does urbanization decrease diversity in ground beetle (Carabidae) assemblages? - Glob. Ecol. Biogeogr. 19: 16-26. doi: http://dx.doi. org/10.1111/j.1466-8238.2009.00499.x

Malmgren, J. C. (2002): How does a newt find its way from a pond? Migration patterns after breeding and metamorphosis in great crested newts (Triturus cristatus) and smooth newts (T. vulgaris). - Herpetol. J. 12: 29-35. 
Marián, M. (1963): A Közép-Tisza kétéltű és hüllő világa. - In: Bálint, A. (szerk.): Móra Ferenc Múzeum Évkönyve. Szegedi Nyomda Vállalat, Szeged, pp. 207-231.

Marián, M. (1966): The Herpetofauna of the Feherto (Lake Feher) near Kardoskut, Hungary. - Vertebrata Hung. 8: 93-101.

Mattfeldt, S. D. \& Grant, E. H. C. (2007): Are two methods better than one? Area constrained transects and leaf litterbags for sampling stream salamanders. - Herpetol. Rev. 38: 43-45.

Méhely, L. (1904): A Mecsekhegység és a Kapela herpetológiai viszonyai. - Állattani Közlem. 3: 241-289.

Mérő, T. O., Bocz, R., Polyák, L., Horváth, G. \& Lengyel, S. (2015): Local habitat management and landscape-scale restoration influence small-mammal communities in grasslands. - Anim. Conserv. 18: 442-450. doi: http://dx.doi.org/10.1111/acv.12191

Mester, B. (2011): Az Egyek-Pusztakócsi mocsárrendszer (Hortobágyi NP) területén zajló természetvédelmi kezelések herpetofaunára gyakorolt hatásainak vizsgálata, különös tekintettel a Feketerét kétéltüfaunájára. - MSc dolgozat, Debreceni Egyetem TTK, Debrecen, 40 p.

Mester, B., Lengyel, S. \& Puky, M. (2015a): Low frequency of amphibian morphological anomalies in a large protected wetland and grassland complex in Hungary. - Herpetol. Conserv. Biol. 10: 679-687.

Mester, B., Szalai, M., Mérő, T. O., Puky, M. \& Lengyel, S. (2015b): Spatiotemporally variable management by grazing and burning increases marsh diversity and benefits amphibians: A field experiment. - Biol. Conserv. 192: 237-246.doi: http://dx.doi.org/10.1016/j.biocon.2015.09.030

Nagy, G. G. \& Lengyel, S. (2008): Egyek-Pusztakócs (Hortobágy) madárvilága 2004 és 2006 között: a tájrehabilitáció második ütemének kezdeti hatásai. - Aquila 114-115: 9-25.

Olson, D. H., Aanensen, D. M., Ronnenberg, K. L., Powell, C. I., Walker, S. F., Bielby, J., Garner, T. W. J., Weaver, G., The Bd Mapping, G. \& Fisher, M. C. (2013): Mapping the Global Emergence of Batrachochytrium dendrobatidis, the Amphibian Chytrid Fungus. - PLOS ONE 8: e56802. doi: http://dx.doi.org/10.1371/journal.pone.0056802

Puky, M. (2001a): Herpetological methods: I. On the use of the road transect method in surveying amphibians with examples from different zoogeographical regions of Hungary. - Opuscula Zool. 33: 75-81.

Puky, M. (2001b): Kétéltü - hüllő biodiverzitás monitoring a Szamos és a Tisza magyarországi szakaszán. - In: Röfler, J. (szerk.): Civilek a Tiszáért. Zöldike könyvsorozat: 9. Nimfea Természetvédelmi Egyesület, Szarvas, pp. 202-207.

Puky, M. (2007): Kétéltủ és hüllőkutatás a Magyar Dunakutató Állomáson. - In: Nosek, J. \& Oertel, N. (szerk.): "A Dunának, mely múlt, jelen s jövendő...": 50 éves az MTA Magyar Dunakutató Állomása (1957-2007): szemelvények az állomás tudományos eredményeiből. MTA ÖBKI-MDÁ, Vácrátót, Göd, pp. 97-107.

Puky, M. \& Fodor, A. (2002): Occurrence of amphibian deformities along the Hungarian section of the River Danube, Tisza and Ipoly. - Limnological Rep. 34: 845-852.

Puky, M.; Schád, P. és Szövényi, G. (2005): Magyarország herpetológiai atlasza. Herpetological atlas of Hungary. - Varangy Akciócsoport Egyesület, Budapest, 207 p.

Rácz, I. A., Déri, E., Kisfali, M., Batiz, Z., Varga, K., Szabó, G. \& Lengyel, S. (2013): Early changes of orthopteran assemblages after grassland restoration: a comparison of space-for-time substitution versus repeated measures monitoring. - Biodiv. Conserv. 22: 2321-2335. doi:http://dx.doi. org/10.1007/s10531-013-0466-8

Sanderson, E. W., Jaiteh, M., Levy, M. A., Redford, K. H., Wannebo, A. V. \& Woolmer, G. (2002): The Human Footprint and the Last of the Wild. - BioScience 52: 891-904. doi: http://dx.doi.org/ 10.1641/0006-3568(2002)052[0891:THFATL]2.0.CO;2 
Semlitsch, R. D. (2000): Principles for Management of Aquatic-Breeding Amphibians. - J. Wildlife Manage. 64: 615-631. doi: http://dx.doi.org/10.2307/3802732

Semlitsch, R. D. (2008): Differentiating Migration and Dispersal Processes for Pond-Breeding Amphibians. - J. Wildlife Manage. 72: 260-267. doi: http://dx.doi.org/10.2193/2007-082

Sewell, D. (2006): Detecting amphibian presence: more visits or more methods? - FrogLog 76: 2-3.

Smith, M. A. \& Green, D. M. (2005): Dispersal and the metapopulation paradigm in amphibian ecology and conservation: are all amphibian populations metapopulations? - Ecography 28: 110-128. doi:http://dx.doi.org/10.1111/j.0906-7590.2005.04042.x

Smith, R. K. \& Sutherland, W. J. (2014): Amphibian conservation: Global evidence for the effects of interventions. - Pelagic Publishing, Exeter, 280 p.

Solti, B. \& Varga, A. (1981): A Mátra hegység kétéltü faunája. - Fol. Hist.-nat. Mus. Matr. 7: 81-101.

Szép, T., Margóczi, K., Tóth, A. (2011): Biodiverzitás Monitorozás. Elektronikus tananyag. Nyíregyházi Egyetem, Nyíregyháza, 180 p.

Szép, T. \& Nagy, K. (2001): Magyarországi UTM kvadrátok térinformatikai adatbázisa a Magyar Madártani és Természetvédelmi Egyesületnél. - Természetvédelmi Közlem. 9: 31-37.

Tóth, M. \& Puky, M. (2009): Kétéltűek hangmonitorozása a Rétközi-tó térségében. - Természetvédelmi Közlem. 15: 467-475.

Vitt, L. J. \& Caldwell, J. P. (2014): Herpetology: An Introductory Biology of Amphibians and Reptiles. - Elsevier 757 p.

Vörös, J., Kiss, I. \& Puky, M. (2015): Conservation and decline of amphibians in Hungary. - In: Heatwole, H. \& Wilkinson, J. W. (szerk.): Amphibian Biology. Pelagic Publishing, Exeter, UK, pp. 99-130.

Vörös, J. \& Major, Á. (2007): Kétéltű-populációk földrajzi szerkezete a Kárpát-medencében. In: Forró, L. (szerk.): A Kárpát-medence állatvilágának kialakulása. A Kárpát-medence állattani értékei és faunájának kialakulása. Magyar Természettudományi Múzeum, Budapest, pp. 269-282.

Wagner, N., Rödder, D., Brühl, C. A., Veith, M., Lenhardt, P. P. \& Lötters, S. (2014): Evaluating the risk of pesticide exposure for amphibian species listed in Annex II of the European Union Habitats Directive. - Biol. Conserv. 176: 64-70. doi: http://dx.doi.org/10.1016/j.biocon.2014.05.014 


\title{
Amphibian fauna of the Egyek-Pusztakócs marsh and grassland system (Hortobágy National Park, East Hungary)
}

\author{
Béla Mester ${ }^{*}$, Márton Szabolcs ${ }^{1}$, Mónika Szalai², Mihály Tóth $^{3}$, \\ Thomas Oliver Mérö ${ }^{1,4}$, Csaba Szepesváry ${ }^{1}$, László Polyák ${ }^{5}$, Miklós \\ Puky $^{6 \dagger}$ and Szabolcs Lengyel ${ }^{1}$ \\ ${ }^{1} M T A$, Centre for Ecological Research (CER), Danube Research Institute (DRI), \\ Department of Tisza River Research, \\ H-4026 Debrecen, Bem tér 18/c, Hungary \\ ${ }^{2}$ Körös-Maros National Park Directorate, Department of Nature Conservation and \\ Grants Coordination, \\ H-5540 Szarvas, Anna-liget 1, Hungary \\ ${ }^{3}$ Örségi National Park Directorate, \\ H-9941 Öriszentpéter, Siskaszer 26/a, Hungary \\ ${ }^{4}$ Nature Protection and Study Society - NATURA, \\ 25000 Sombor, Milana Rakića 20, Serbia \\ ${ }^{5}$ BioAqua Pro Kft., \\ H-4032 Debrecen, Soó Rezsö utca 21, Hungary \\ ${ }^{6}$ MTA CER DRI, Department of Restoration and Animal Ecology, \\ H-1113 Budapest, Karolina út 29, Hungary \\ e-mail: mester.bela@okologia.mta.hu
}

Accurate data on the occurrence and distribution of amphibian species are fundamental for conservation, especially in valuable areas with little previous knowledge. Here we present occurrence data for amphibian species in the Egyek-Pusztakócs marsh and grassland system (Hortobágy National Park, East Hungary). We used five methods for surveying amphibians (visual encounter surveying, acustic monitoring, visual and acustic surveying in transects, combined surveys, bottle traps, hand netting) in several field surveys. We observed a total of 14,362 individuals of 11 amphibian species (Common Newt, Danube Crested Newt, Fire-bellied Toad, Common Spadefoot, Common Toad, Green Toad, Common Tree Frog, Moor Frog, Pool Frog, Marsh Frog, Edible Frog). The diversity profiles of the six most intensively surveyed $2.5 \times 2.5 \mathrm{~km}$ UTM cells showed no differences, indicating a homogeneous distribution of species in the marsh system. Our dataset expands the number of species detected in the two 10x10-km UTM cells covering the area by five and seven new species, respectively. We found large populations of two species (Danube Crested Newt (Triturus dobrogicus) and Fire-bellied Toad (Bombina bombina) listed on Annex II of the Habitats Directive. Landscape- and habitat-scale heterogeneity sustained by local conservation actions (grassland restoration and marsh management) can maintain diverse local amphibian assemblages, which highlights the importance of the marsh system.

Keywords: anurans, habitat management, herpetofauna, Hortobágy, monitoring, Natura 2000, reconstruction, urodeles 